\title{
Lifestyle Factors and Coronary Artery Calcification
}

\author{
Chong-Do Lee ${ }^{a}$ Sae Young Jae ${ }^{b}$ \\ ${ }^{a}$ Healthy Lifestyles Research Center, Arizona State University, Phoenix, Ariz., USA; \\ ${ }^{b}$ Health and Integrative Physiology Laboratory, University of Seoul, Seoul, South Korea
}

\section{Key Words}

Lifestyle factors · Coronary artery calcification · Subclinical atherosclerosis

\begin{abstract}
The effective prevention of cardiovascular disease (CVD) remains a global health challenge. Adopting a combined primary (prevention of the first episode of coronary heart disease or stroke) and primordial (prevention of the causal risk factors of CVD) prevention strategy is the best approach to prevent CVD. Most importantly, the primordial prevention strategy should in the first place be to promote cardiovascular health across individual and population levels by improving the underlying causal risk factors for CVD (i.e., unhealthy diets, physical inactivity, obesity, and cigarette smoking). Epidemiological evidence indicates that maintaining favorable underlying risk factors (lifestyle factors) is associated with a lower risk of incident CVD. Prevention of early atherosclerotic vascular disease is also an important strategy to prevent CVD. However, there has been limited research on the association between lifestyle factors and early atherosclerotic vascular disease (i.e., coronary or carotid atherosclerosis) across race and gender groups in population-based studies. This article briefly reviews whether lifestyle factors relate to subclinical atherosclerosis as assessed by coronary artery calcification in asymptomatic individuals.

(c) 2015 S. Karger AG, Basel
\end{abstract}

\section{Introduction}

Cardiovascular disease (CVD) is the leading cause of global mortality, leading to more than 17 million deaths annually [1]. With economic development, CVD mortality rates have substantially increased in developing countries [2], while having declined in developed countries over the past 4 decades [3]. Approximately $80 \%$ of the CVD burden arises from low- and 
middle-income countries, and continuous efforts are needed to preventCVD in both developed and developing countries [1]. The establishment of an effective CVD prevention strategy in developed countries may be potentially valuable in preventing CVD in developing countries. As a CVD prevention strategy, most developed countries have adopted primary prevention [prevention of the first episode of coronary heart disease (CHD) or stroke] focusing on treatment of high-risk individuals who already have known risk factors (i.e., hypertension, dyslipidemia, and diabetes) [4]. Identifying high-risk individuals is fundamental to the practice of primary prevention and to prevent the progression of atherosclerotic vascular disease. Guidelines in the US, Europe, and Canada have included traditional CVD risk factors (i.e., hypertension, dyslipidemia, cigarette smoking, and diabetes) to detect coronary disease risk [5-7]. These four traditional CVD risk factors explain about $87 \%$ of CHD or $85 \%$ of CVD deaths; this also shows that persons with zero risk factors have low CHD or CVD death rates $[8,9]$. Most individuals with fatal CHD $(\geq 87 \%)$ had $\geq 1$ elevated traditional CVD risk factor [10]. Thus, maintaining optimal risk factors (i.e., total cholesterol $<200 \mathrm{mg} / \mathrm{dl}$, systolic blood pressure $<120 \mathrm{~mm} \mathrm{Hg}$, diastolic blood pressure $<80 \mathrm{~mm} \mathrm{Hg}$, no diabetes, not smoking) is important to prevent CVD for a lifetime. This primary CVD prevention strategy has significantly contributed to reducing CHD or stroke mortality in the US by lowering the prevalence of several traditional CVD risk factors including hypertension, high cholesterol, and cigarette smoking [11]. Conversely, the emphasis on this primary prevention approach has also produced a higher prevalence of obesity and diabetes in the US [11]. This increasing trend may significantly influence the burden of CHD or stroke mortality. Notably, the prevalence of optimal risk factors in US communities is low at approximately $3-10 \%[9,11]$. This clearly documents a tremendous gap between primary prevention strategies and cardiovascular health status. To resolve this issue, adopting primordial prevention in addition to primary prevention is imperative to prevent CVD. In fact, primordial prevention is the ideal approach for improving underlying causal risk factors of CVD (i.e., unhealthy diets, physical inactivity, obesity, and smoking). These underlying risk factors (lifestyle factors) are associated with clinical CVD risk factors [12]. The continuing message is that favorable underlying lifestyle factors are associated with a lower risk of incident CHD and all-cause mortality [13-15]. Thus, increasing healthy populations by promoting healthy lifestyle behaviors at the individual and population level should in the first place be to avoid the burden of traditional CVD risk factors.

To address CVD prevention strategies, it is important to identify causal risk factors associated with early atherosclerotic vascular disease (coronary and carotid atherosclerosis). The American Heart Association (AHA) recently initiated a new approach to improving cardiovascular health, focusing on a healthy diet, regular exercise, not smoking, and managing normal weight [16]. Nonetheless, the health benefits of these favorable lifestyle factors in relation to early atherosclerotic vascular disease remain poorly documented. In this review, we examine whether lifestyle factors relate to subclinical atherosclerosis as assessed by coronary artery calcification (CAC) in population-based cross-sectional and longitudinal studies (table 1).

\section{Subclinical Atherosclerosis: CAC}

Approximately $50 \%$ of first coronary events occur in healthy men and women without prior symptoms. Of these, about $25 \%$ are sudden death or nonfatal myocardial infarction [17]. Therefore, identifying early atherosclerotic vascular disease (i.e., atherosclerosis) and subsequent treatment is an important strategy to prevent CVD. Atherosclerosis is a major cause of CHD and stroke. Monocyte-derived macrophages and other phagocytes are believed to contribute to vascular injury and atherosclerotic progression [18]. The plaque 
Table 1. Lifestyle factors and CAC

\begin{tabular}{|c|c|c|c|c|c|c|}
\hline Study & Year & Study population & $\begin{array}{l}\text { Exposure } \\
\text { comparison }\end{array}$ & $\begin{array}{l}\text { Outcome } \\
\text { (events, n) }\end{array}$ & $\begin{array}{l}\text { OR } \\
(95 \% \mathrm{CI})\end{array}$ & $\begin{array}{l}\mathrm{p} \\
\text { value }\end{array}$ \\
\hline \multicolumn{7}{|l|}{ Abdominal obesity ${ }^{\mathrm{a}}$} \\
\hline Lee et al. [26] & 2009 & $\begin{array}{l}\text { CARDIA study ( } 2,951 \text { US men } \\
\text { and women; age } 18-30 \text { years })\end{array}$ & $\begin{array}{l}\text { Waist girth (highest vs. } \\
\text { lowest tertile) }\end{array}$ & $\begin{array}{l}\mathrm{CAC}>0 \\
(\mathrm{n}=277)\end{array}$ & $\begin{array}{l}1.90 \\
(1.36,2.65)\end{array}$ & $<0.001$ \\
\hline \multirow[t]{2}{*}{ Choi et al. [27] } & 2010 & $\begin{array}{l}\text { Hospital health care study }(1,336 \\
\text { Korean men; age } 30 \text {-86 years })\end{array}$ & $\begin{array}{l}\text { Waist girth (quartile } 4 \text { vs. } \\
\text { quartiles } 1-3 \text { ) }\end{array}$ & $\begin{array}{l}\text { CAC >100 } \\
(n=236)\end{array}$ & $\begin{array}{l}1.56 \\
(1.12,2.18)\end{array}$ & 0.01 \\
\hline & & & $\begin{array}{l}\text { Visceral fat (quartile } 4 \text { vs. } \\
\text { quartiles } 1-3 \text { ) }\end{array}$ & $\begin{array}{l}\mathrm{CAC}>100 \\
(\mathrm{n}=236)\end{array}$ & $\begin{array}{l}1.42 \\
(1.01,1.98)\end{array}$ & 0.043 \\
\hline \multirow[t]{2}{*}{ Fox et al. [28] } & 2009 & $\begin{array}{l}\text { Framingham Heart Study }(3,130 \\
\text { US men and women; mean age }\end{array}$ & $\begin{array}{l}\text { Waist girth (quartile } 4 \text { vs. } \\
\text { quartile 1) }\end{array}$ & $\begin{array}{l}\text { CAC }>0 \\
(n=457)\end{array}$ & $\begin{array}{l}1.18 \\
(0.85,1.64) \\
\end{array}$ & 0.32 \\
\hline & & 52 years) & $\begin{array}{l}\text { Visceral fat (quartile } 4 \text { vs. } \\
\text { quartile 1) }\end{array}$ & $\begin{array}{l}\text { CAC }>0 \\
(\mathrm{n}=457)\end{array}$ & $\begin{array}{l}0.87 \\
(0.61,1.23)\end{array}$ & 0.43 \\
\hline Liu et al. [29] & 2012 & $\begin{array}{l}\text { Jackson Heart Study (2,884 African } \\
\text { Americans; mean age } 60 \text { years) }\end{array}$ & Visceral fat (per SD) & $\begin{array}{l}\text { CAC }>0 \\
(n=1,384)\end{array}$ & $\begin{array}{l}1.07 \\
(0.9,1.2)\end{array}$ & 0.28 \\
\hline \multicolumn{7}{|l|}{ Physical fitness ${ }^{\mathrm{b}}$} \\
\hline Lee et al. [31] & 2009 & $\begin{array}{l}\text { CARDIA study }(2,373 \text { US men } \\
\text { and women; age } 18-30 \text { years })\end{array}$ & $\begin{array}{l}\text { High vs. low (quartile } 4 \text { vs. } \\
\text { quartile 1) }\end{array}$ & $\begin{array}{l}\text { CAC }>0 \\
(n=219)\end{array}$ & $\begin{array}{l}0.59 \\
(0.36,0.97)\end{array}$ & 0.03 \\
\hline DeFina et al. [32] & 2014 & $\begin{array}{l}\text { Cooper center ( } 5,341 \text { US women; } \\
\text { age } 40-90 \text { years) }\end{array}$ & MET & $\begin{array}{l}\mathrm{CAC}>0 \\
(\mathrm{n}=1,062)\end{array}$ & $\begin{array}{l}0.96 \\
(0.92,1.01)\end{array}$ & 0.35 \\
\hline \multicolumn{7}{|l|}{ Physical activity ${ }^{\mathrm{c}}$} \\
\hline Lee et al. [31] & 2009 & $\begin{array}{l}\text { CARDIA study }(2,373 \text { US men } \\
\text { and women; age } 33-45 \text { years })\end{array}$ & $\begin{array}{l}\text { High vs. low (quartile } 4 \text { vs. } \\
\text { quartile 1) }\end{array}$ & $\begin{array}{l}\text { CAC }>0 \\
(n=219)\end{array}$ & $\begin{array}{l}0.96 \\
(0.63,1.47)\end{array}$ & 0.82 \\
\hline Bertoni et al. [33] & 2008 & $\begin{array}{l}\text { MESA study }(6,482 \text { US adults; } \\
\text { age } 45 \text { - } 84 \text { years })\end{array}$ & $\begin{array}{l}\text { High vs. low (intentional } \\
\text { exercise: } \geq 30 \mathrm{MET} \text { h/week } \\
\text { vs. none) }\end{array}$ & $\begin{array}{l}\text { CAC >0 } \\
(M=1,900 \\
W=1,371)\end{array}$ & $\begin{array}{l}1.05(\mathrm{M}) \\
(0.98,1.12) \\
1.02(\mathrm{~W}) \\
(0.93,1.12)\end{array}$ & $>0.05$ \\
\hline \multicolumn{7}{|l|}{ Cigarette smoking } \\
\hline Loria et al. [41] & 2007 & $\begin{array}{l}\text { CARDIA study ( } 2,433 \text { US men } \\
\text { and women; age } 18-30 \text { years) }\end{array}$ & $\begin{array}{l}\text { Cigarette smoking ( }>10 \\
\text { vs. }<10 \text { cigarettes/day) }\end{array}$ & $\begin{array}{l}\text { CAC }>0 \\
(\mathrm{n}=231)\end{array}$ & $\begin{array}{l}1.25 \\
(1.05,1.48)\end{array}$ & $<0.05$ \\
\hline $\begin{array}{l}\text { Lehmann et al. } \\
{[42]}\end{array}$ & 2014 & $\begin{array}{l}\text { Heinz Nixdorf Recall study } \\
(1,261 \text { German men and women; } \\
\text { age } 45-75 \text { years })\end{array}$ & Current smoker (yes vs. no) & $\begin{array}{l}\text { CAC }>0 \\
(n=317)\end{array}$ & $\begin{array}{l}1.49 \\
(1.04,2.15)\end{array}$ & $<0.05$ \\
\hline $\begin{array}{l}\text { Alcohol intake } \\
\text { Pletcher et al. } \\
{[44]}\end{array}$ & 2006 & $\begin{array}{l}\text { CARDIA study ( } 3,037 \text { US men } \\
\text { and women; age, } 33-45 \text { years) }\end{array}$ & $\begin{array}{l}\text { Heavy vs. never } \\
\text { (>14 vs. } 0 \text { drinks/week) }\end{array}$ & $\begin{array}{l}\text { CAC }>0 \\
(n=260)\end{array}$ & $\begin{array}{l}1.9 \\
(1.2,2.9)\end{array}$ & 0.002 \\
\hline $\begin{array}{l}\text { McClelland } \\
\text { et al. [45] }\end{array}$ & 2008 & $\begin{array}{l}\text { MESA study (6,791 US adults; } \\
\text { age } 45-84 \text { years) }\end{array}$ & $\begin{array}{l}\text { Heavy vs. none } \\
\text { (>2 vs. } 0 \text { drinks/day) }\end{array}$ & $\mathrm{CAC}>0$ & $\begin{array}{l}1.09 \\
(0.66,1.79)\end{array}$ & 0.83 \\
\hline Tofferi et al. [46] & 2004 & $\begin{array}{l}\text { US Army Personnel study ( } 731 \\
\text { men and women; age } 39-45 \text { years) }\end{array}$ & $\begin{array}{l}\text { Heavy vs. none } \\
\text { ( } \geq 2 \text { vs. } 0 \text { drinks/day) }\end{array}$ & $\begin{array}{l}\text { CAC }>0 \\
(\mathrm{n}=135)\end{array}$ & $\begin{array}{l}1.26 \\
(0.69,2.59)\end{array}$ & $>0.05$ \\
\hline
\end{tabular}

a Abdominal obesity was defined as follows: waist girth $\geq 84.3 \mathrm{vs.}<77.5 \mathrm{~cm}$ (men) and $\geq 75.5 \mathrm{vs.}<68 \mathrm{~cm}$ (women) [26]; waist girth $>93.3$ vs. $\leq 93.3 \mathrm{~cm}$ (men), visceral fat $>173$ vs. $\leq 173 \mathrm{~cm}^{2}$ (men) [27]; waist girth $>106.7 \mathrm{vs.} \leq 89.7 \mathrm{~cm}$ (men) and $\geq 101.1 \mathrm{vs.}<80.8 \mathrm{~cm}$ (men), visceral fat $>2,794$ vs. $\leq 1,457 \mathrm{~cm}^{3}$ (men) and $>1,804$ vs. $<681 \mathrm{~cm}^{3}$ (women) [28]; continuous quantity of visceral fat (cm ${ }^{3}$ ) [28].

${ }^{\mathrm{b}}$ Physical fitness was defined as follows: treadmill time $\geq 13.5 \mathrm{vs}$. $<11 \mathrm{~min}$ (men) and $\geq 10 \mathrm{vs}$. $<7.3 \mathrm{~min}$ (women) [31]; MET achieved on treadmill test (1 MET $=3.5 \mathrm{ml} \mathrm{O} / \mathrm{kg} / \mathrm{min}$ ) [32].

${ }^{c}$ Physical activity was defined as follows: physical activity levels $\geq 688$ vs. $<272$ units (men) and $\geq 478$ vs. $<150$ units (women) [31]; intentional exercise ( $\geq 30$ MET h/week vs. none) [33].

formation and calcium deposition is associated with an accumulation of microphages, smooth muscle cells, fibrosis, necrosis, and lipids in the artery [19]. CAC is a risk marker for atherosclerosis. It is a noninvasive measure of subclinical atherosclerosis and has a superior discriminating power for CVD events compared with other markers of atheroscle- 
rosis including carotid intima-media thickness or the ankle-brachial index [20, 21]. Significant CAC scores have a greater accuracy in detecting CHD in persons with stenosis $>50 \%$ [22]. CAC is a strong independent predictor of CVD events and all-cause mortality [23]. Individuals with a CAC score of 0 have a very low rate of CVD events [24]. In general, the established risk factors for CAC are similar to those for clinical CVD.

\section{Adiposity and CAC}

Excess adiposity is mainly due to unhealthy diets and sedentary lifestyles. Particularly, abdominal obesity is a significant risk factor for atherosclerosis. The excessive accumulation of visceral fat is related to insulin resistance and hyperinsulinemia, which contribute to atherosclerotic progression [25]. Abdominal obesity is also positively associated with low-density lipoprotein cholesterol (LDL-C) and oxidized LDL-C, which relates to endothelial cell injury and thrombus formation [19]. The Coronary Artery Risk Development in Young Adults (CARDIA) study showed that abdominal obesity measured by waist girth in young adults (aged 18-30 years) was directly associated with early atherosclerotic vascular disease assessed by CAC over 15 years (aged 33-45 years) [26]. At baseline, young adults with the highest tertile of waist girth (men $\geq 84.3 \mathrm{~cm}$; women $\geq 75.5 \mathrm{~cm}$ ) had twice the risk of developing CAC when compared with young adults in the lowest tertile category (men $<77.5 \mathrm{~cm}$; women $<68 \mathrm{~cm}$ ) 15 years later. A Korean cross-sectional study also showed that abdominal adiposity measured by waist girth (quartile 4 vs. quartiles $1-3$ ) or visceral fat (quartile 4 vs. quartiles 1-3) was positively associated with CAC in Korean men aged 30-86 years [27]. In contrast, other (cross-sectional) US studies including the Framingham Heart Study and the Jackson Heart Study showed that abdominal obesity measured by waist girth or visceral fat was not related to CAC in US men and women [28, 29]. More longitudinal studies are needed to determine the association between abdominal obesity and CAC across race and gender groups. Further studies are also needed to determine optimal cut points for waist girth or visceral fat associated with the minimum risk of developing CAC. Some investigators have even reported that atherosclerosis does not progress when LDL-C is $<67$ $\mathrm{mg} / \mathrm{dl}[30]$.

\section{Physical Activity or Physical Fitness and CAC}

Physical fitness, an objective marker of physical activity determined by behavioral and environmental factors, genetics, and subclinical disease, is a significant predictor of CVD mortality [15]. The CARDIA study showed that physical fitness measured at baseline was inversely associated with early atherosclerotic vascular disease in young adults. High-fitness young adults (treadmill time: men $\geq 13.5 \mathrm{~min}$, women $\geq 10 \mathrm{~min}$; age 18-30 years) had a $41 \%$ lower risk of having CAC as compared with low-fitness counterparts (treadmill time: men $<11$ min, women $<7.3 \mathrm{~min}$ ) over 15 years [31]. One cross-sectional study showed a null association between physical fitness, as assessed by continuous metabolic equivalents (MET; 1 $\mathrm{MET}=3.5 \mathrm{ml} \mathrm{O}_{2} / \mathrm{kg} / \mathrm{min}$ ), and CAC in US women aged $40-90$ years [32]. Interestingly, several population-based studies indicate no association between physical activity and CAC. The Multi-Ethnic Study of Atherosclerosis (MESA) and the CARDIA study have shown that physical activity was not associated with CAC $[31,33]$. This may be due to the inaccurate measurement of physical activity in both cross-sectional and observational studies. More studies are needed to determine with a more precise measurement the relation of physical activity to CAC. Further studies are also needed to establish optimal cut points for physical fitness or physical 


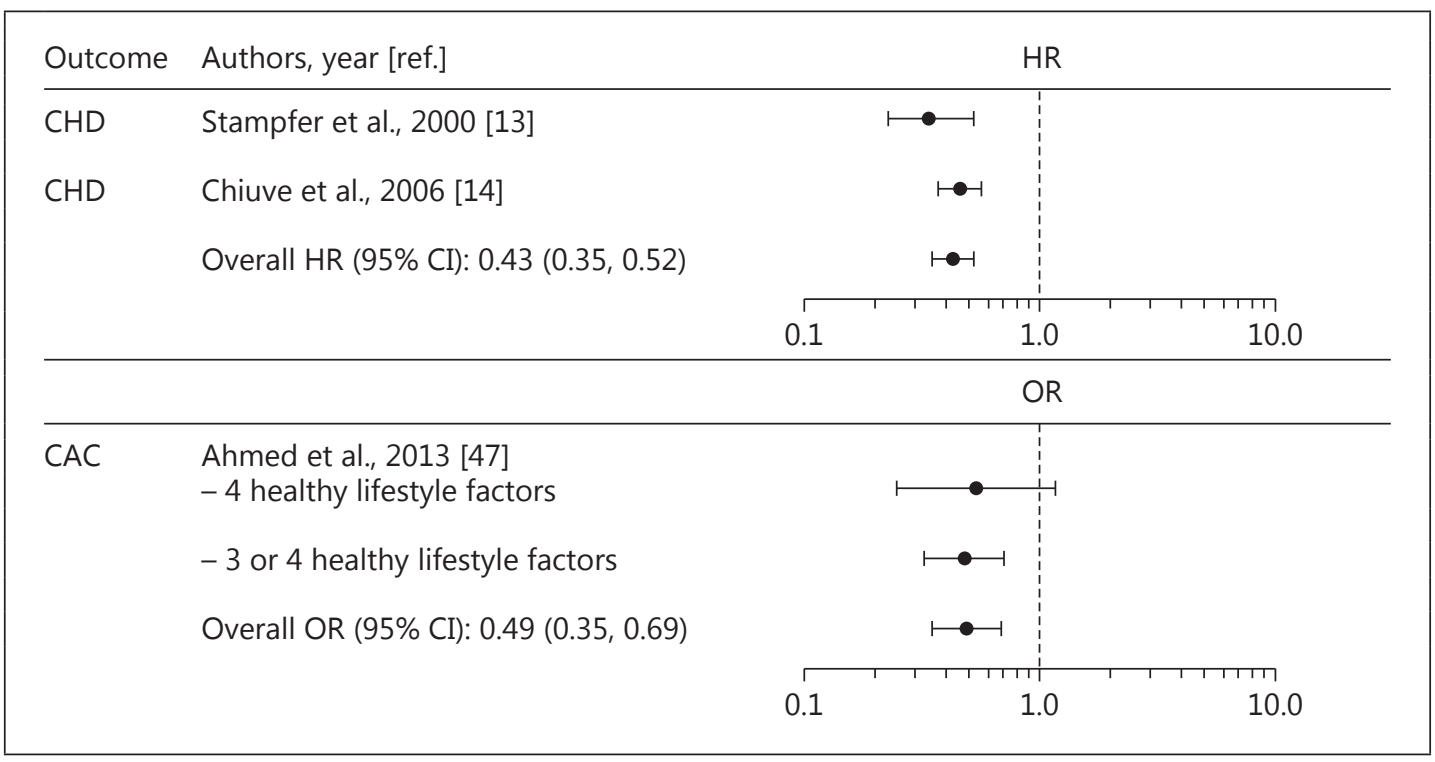

Fig. 1. Risk of coronary events or CAC by the combination of healthy lifestyle factors: a healthy diet (top $40 \%$ of healthy eating scores), regular exercise (moderate-to-vigorous activity $>30 \mathrm{~min} /$ day), weight control $(\mathrm{BMI}<25)$, tobacco avoidance versus 0 healthy lifestyle factors. Combination of healthy lifestyle factors in $\mathrm{CAC}$ was classified as these 4 healthy lifestyle factors or $\geq 3$ versus 0 healthy lifestyle factors. Error bars represent $95 \%$ CI for each $\mathrm{HR}$ or OR.

activity associated with a minimum risk of developing CAC. Although excessive exercise may be harmful to patients with chronic diseases [34], mounting evidence indicates that improvements in fitness reduce blood pressure and improve lipid profiles, endothelial function, and antioxidant defense systems $[35,36]$. To date, the global fitness standards in men and women have not been fully explored. Establishing accurate fitness standards in relation to minimum CVD mortality or CAC risk across age, gender, and race groups is an important strategy for improving cardiovascular health.

\section{Cigarette Smoking and CAC}

Cigarette smoking is a potent risk factor for atherosclerosis. Life expectancy in smokers is reduced by an average of 13.2 years for men and 14.5 years for women [37]. Cigarette smoking produces numerous toxic chemicals and free radicals, which induce endothelial cell injury and subsequent atherosclerotic progression. Cigarette smoking is also associated with endothelial dysfunction by elevating platelet aggregability, fibrinogen levels, endothelial permeability and plasma viscosity and by lowering HDL cholesterol [38]. Approximately $50-62 \%$ of smokers have CAC scores of $>0[39,40]$. The CARDIA study and the Heinz Nixdorf Recall study have shown that current smoking was positively associated with CAC [41, 42]. Even smokers with a CAC score of 0 had a greater all-cause mortality compared with nonsmokers with a CAC score of 0 [42]. A lifetime of not smoking would show benefit in reducing the risk of developing CAC. 


\section{Alcohol Intake and CAC}

Moderate alcohol intake is associated with a lower risk of incident CHD, but it still has a potential link to cancer mortality [43]. Thus, recommending moderate alcohol intake to the public requires more careful consideration. The association between alcohol intake and CAC remains controversial. Some investigators found a positive association between heavy alcohol intake (>14 drinks/week) and risk of developing CAC [44]. Other studies have shown no association between heavy alcohol intake ( $>2$ drinks/day) and CAC $[45,46]$. More studies are needed to determine whether moderate or heavy alcohol intake relates to CAC.

\section{Combined Effects of Lifestyle Factors and CAC}

Few studies have examined the combined impact of healthy lifestyle behaviors on CAC. The MESA showed that persons who exercised regularly ( $>150 \mathrm{~min} /$ week of moderate activity or $>75 \mathrm{~min} /$ week of vigorous activity), had a healthy diet (Mediterranean diet), never smoked, and maintained a normal body weight $(18.5 \leq \mathrm{BMI}<25)$ had $46 \%$ lower odds of having CAC compared with persons with 0 low-risk lifestyle behaviors [47]. Persons with $\geq 3$ healthy lifestyle behaviors had approximately 52\% lower odds of having CAC as compared with persons with 0 low-risk lifestyle behaviors. Persons who adopted the 4 healthy lifestyles mentioned above also showed a slower annual progression of calcium scores [47]. Several clinical trials including the Lifestyle Heart Trial [48], the Stanford Coronary Risk Intervention Project [49], and the Heidelberg Regression Study [50] also showed that coronary artery disease patients who had exercise training with a low-fat diet [50] or exercise training with other lifestyle modification (not smoking, low-fat diet, and stress management) $[48,49]$ had a slower progression of coronary atherosclerosis as compared with control patients with coronary artery disease.

\section{Conclusion}

Epidemiologic evidence indicates that maintaining a healthy lifestyle (a healthy diet, regular exercise, weight control, and tobacco avoidance) is associated with a lower risk of CVD events (fig. 1). Few studies also show that maintaining these healthy lifestyles is associated with a lower risk of developing CAC. However, whether these lifestyle factors alter early atherosclerotic vascular disease risk is less clear. More longitudinal studies and randomized controlled trials are needed to determine the effect of a single and a combined number of lifestyle factors or novel risk factors on CAC. Further studies are also needed to establish the optimal cut points of lifestyle factors associated with a minimum risk of developing CAC across race, gender, and age groups in population-based studies. The establishment of these cut points will play a fundamental role in preventing early atherosclerotic vascular disease and promoting cardiovascular health worldwide.

\section{Disclosure Statement}

The authors have no conflicts of interest to disclose. 
Lee and Jae: Lifestyle Factors and Coronary Artery Calcification

\section{References}

1 World Health Organization: Global Atlas on Cardiovascular Disease Prevention and Control. Geneva, World Health Organization, 2011.

2 Reddy KS, Yusuf S: Emerging epidemic of cardiovascular disease in developing countries. Circulation 1998;97: 596-601.

3 Cooper R, Cutler J, Desvigne-Nickens P, Fortmann SP, Friedman L, Havlik R, et al: Trends and disparities in coronary heart disease, stroke, and other cardiovascular diseases in the United States: findings of the national conference on cardiovascular disease prevention. Circulation 2000;102:3137-3147.

4 Expert Panel on Detection, Evaluation, and Treatment of High Blood Cholesterol in Adults: Executive summary of the third report of the National Cholesterol Education Program (NCEP) Expert Panel on Detection, Evaluation, and Treatment of High Blood Cholesterol in Adults (Adult Treatment Panel III). JAMA 2001;285:24862497.

5 Greenland P, Alpert JS, Beller GA, Benjamin EJ, Budoff MJ, Fayad ZA, et al; American College of Cardiology Foundation/American Heart Association Task Force on Practice Guidelines: 2010 ACCF/AHA guideline for assessment of cardiovascular risk in asymptomatic adults: a report of the American College of Cardiology Foundation/American Heart Association Task Force on Practice Guidelines. Circulation 2010;122:e584-e636.

6 Perk J, De Backer G, Gohlke H, Graham I, Reiner Z, Verschuren WM, et al; European Association for Cardiovascular Prevention and Rehabilitation; ESC Committee for Practice Guidelines: European guidelines on cardiovascular disease prevention in clinical practice (version 2012): the Fifth Joint Task Force of the European Society of Cardiology and Other Societies on Cardiovascular Disease Prevention in Clinical Practice (constituted by representatives of nine societies and by invited experts). Eur Heart J 2012;33:1635-1701.

7 Anderson TJ, Grégoire J, Hegele RA, Couture P, Mancini GB, McPherson R, et al: 2012 Update of the Canadian Cardiovascular Society guidelines for the diagnosis and treatment of dyslipidemia for the prevention of cardiovascular disease in the adult. Can J Cardiol 2013;29:151-167.

8 Stamler J, Wentworth D, Neaton JD: Is relationship between serum cholesterol and risk of premature death from coronary heart disease continuous and graded? Findings in 356,222 primary screenees of the Multiple Risk Factor Intervention Trial (MRFIT). JAMA 1986;256:2823-2828.

9 Hozawa A, Folsom AR, Sharrett R, Chambless LE: Absolute and attributable risks of cardiovascular disease incidence in relation to optimal and borderline risk factors: comparison of African American with white subjects - Atherosclerosis Risk in Communities Study. Arch Intern Med 2007;167:573-579.

10 Greenland P, Knoll MD, Stamler J, Neaton JD, Dyer AR, Garside DB, Wilson PW: Major risk factors as antecedents of fatal and nonfatal coronary heart disease events. JAMA 2003;290:891-897.

11 Ford ES, Li C, Zhao G, Pearson WS, Capewell S: Trends in the prevalence of low risk factor burden for cardiovascular disease among United States adults. Circulation 2009;120:1181-1188.

12 Wood PD, Stefanick ML, Dreon DM, Frey-Hewitt B, Garay SC, Williams PT, et al: Changes in plasma lipids and lipoproteins in overweight men during weight loss through dieting as compared with exercise. N Engl J Med 1988;319:1173-1179.

13 Stampfer MJ, Hu FB, Manson JE, Rimm EB, Willett WC: Primary prevention of coronary heart disease in women through diet and lifestyle. N Engl J Med 2000;343:16-22.

14 Chiuve SE, McCullough ML, Sacks FM, Rimm EB: Healthy lifestyle factors in the primary prevention of coronary heart disease among men: benefits among users and nonusers of lipid-lowering and antihypertensive medications. Circulation 2006;114:160-167.

15 Lee CD, Sui X, Blair SN: Combined effects of cardiorespiratory fitness, not smoking, and normal waist girth on morbidity and mortality. Arch Intern Med 2009;169:2096-2101.

16 Lloyd-Jones DM, Hong Y, Labarthe D, Mozaffarian D, Appel LJ, Van Horn L, et al: Defining and setting national goals for cardiovascular health promotion and disease reduction: the American Heart Association's strategic Impact Goal through 2020 and beyond. Circulation 2010;121:586-613.

17 Zipes DP, Wellens HJ: Sudden cardiac death. Circulation 1998;98:2334-2351.

18 Ernst E, Hammerschmidt DE, Bagge U, Matrai A, Dormandy JA: Leukocytes and the risk of ischemic diseases. JAMA 1987;257:2318-2324.

19 Davies MJ: A macro and micro view of coronary vascular insult in ischemic heart disease. Circulation 1990; 82(suppl):II38-II46.

20 Yeboah J, McClelland RL, Polonsky TS, Burke GL, Sibley CT, O'Leary D, et al: Comparison of novel risk markers for improvement in cardiovascular risk assessment in intermediate-risk individuals. JAMA 2012;308:788795.

21 Kavousi M, Elias-Smale S, Rutten JH, Leening MJ, Vliegenthart R, Verwoert GC, et al: Evaluation of newer risk markers for coronary heart disease risk classification: a cohort study. Ann Intern Med 2012;156:438-444.

22 Haberl R, Becker A, Leber A, Knez A, Becker C, Lang C, et al: Correlation of coronary calcification and angiographically documented stenoses in patients with suspected coronary artery disease: results of 1,764 patients. J Am Coll Cardiol 2001;37:451-457.

23 Detrano R, Guerci AD, Carr JJ, Bild DE, Burke G, Folsom AR, et al: Coronary calcium as a predictor of coronary events in four racial or ethnic groups. N Engl J Med 2008;358:1336-1345. 
24 Blaha MJ, Budoff MJ, DeFilippis AP, Blankstein R, Rivera JJ, Agatston A, et al: Associations between C-reactive protein, coronary artery calcium, and cardiovascular events: implications for the JUPITER population from MESA, a population-based cohort study. Lancet 2011;378:684-692.

25 Bierman EL: George Lyman Duff Memorial Lecture. Atherogenesis in diabetes. Arterioscler Thromb 1992;12: 647-656.

26 Lee CD, Jacobs DR Jr, Schreiner PJ, Iribarren C, Hankinson A: Abdominal obesity and coronary artery calcification in young adults: the Coronary Artery Risk Development in Young Adults (CARDIA) Study. Am J Clin Nutr 2007;86:48-54.

27 Choi SY, Kim D, Oh BH, Kim M, Park HE, Lee CH, Cho SH: General and abdominal obesity and abdominal visceral fat accumulation associated with coronary artery calcification in Korean men. Atherosclerosis 2010;213:273278.

28 Fox CS, Hwang SJ, Massaro JM, Lieb K, Vasan RS, O’Donnell CJ, Hoffmann U: Relation of subcutaneous and visceral adipose tissue to coronary and abdominal aortic calcium (from the Framingham Heart Study). Am J Cardiol 2009;104:543-547.

29 Liu J, Musani SK, Bidulescu A, Carr JJ, Wilson JG, Taylor HA, Fox CS: Fatty liver, abdominal adipose tissue and atherosclerotic calcification in African Americans: the Jackson Heart Study. Atherosclerosis 2012;224:521525.

30 Martin SS, Blumenthal RS, Miller M: LDL cholesterol: the lower the better. Med Clin North Am 2012;96:13-26.

31 Lee CD, Jacobs DR Jr, Hankinson A, Iribarren C, Sidney S: Cardiorespiratory fitness and coronary artery calcification in young adults: the CARDIA study. Atherosclerosis 2009;203:263-268.

32 DeFina L, Radford N, Leonard D, Gibbons L, Khera A: Cardiorespiratory fitness and coronary artery calcification in women. Atherosclerosis 2014;233:648-653.

33 Bertoni AG, Whitt-Glover MC, Chung H, Le KY, Barr RG, Mahesh M, et al: The association between physical activity and subclinical atherosclerosis: the Multi-Ethnic Study of Atherosclerosis. Am J Epidemiol 2009;169: 444-454.

34 Sharman JE, La Gerche A, Coombes JS: Exercise and cardiovascular risk in patients with hypertension. Am J Hypertens 2015;28:147-158.

35 Shearman DL: Exercise and endothelial function. Coron Artery Dis 2000;11:117-122.

36 Mora S, Cook N, Buring JE, Ridker PM, Lee IM: Physical activity and reduced risk of cardiovascular events: potential mediating mechanisms. Circulation 2007;116:2110-2118.

37 Centers for Disease Control and Prevention (CDC): Annual smoking-attributable mortality, years of potential life lost, and economic costs - United States, 1995-1999. MMWR Morb Mortal Wkly Rep 2002;51:300-303.

38 O'Brien KD, Chait AC: The biology of the artery wall in atherogenesis. Med Clin North Am 1994;78:41-67.

39 Shaw LJ, Raggi P, Callister TQ, Berman DS: Prognostic value of coronary artery calcium screening in asymptomatic smokers and non-smokers. Eur Heart J 2006;27:968-975.

40 McEvoy JW, Blaha MJ, Rivera JJ, Budoff MJ, Khan AN, Shaw LJ, et al: Mortality rates in smokers and nonsmokers in the presence or absence of coronary artery calcification. JACC Cardiovasc Imaging 2012;5:1037-1045.

41 Loria CM, Liu K, Lewis CE, Hulley SB, Sidney S, Schreiner PJ, et al: Early adult risk factor levels and subsequent coronary artery calcification: the CARDIA study. J Am Coll Cardiol 2007;49:2013-2020.

42 Lehmann N, Möhlenkamp S, Mahabadi AA, Schmermund A, Roggenbuck U, Seibel R, et al: Effect of smoking and other traditional risk factors on the onset of coronary artery calcification: results of the Heinz Nixdorf Recall study. Atherosclerosis 2014;232:339-345.

43 Corrao G, Bagnardi V, Zambon A, La Vecchia C: A meta-analysis of alcohol consumption and the risk of 15 diseases. Prev Med 2004;38:613-619.

44 Pletcher MJ, Varosy P, Kiefe CI, Lewis CE, Sidney S, Hulley SB: Alcohol consumption, binge drinking, and early coronary calcification: findings from the Coronary Artery Risk Development in Young Adults (CARDIA) Study. Am J Epidemiol 2005;161:423-433.

45 McClelland RL, Bild DE, Burke GL, Mukamal KJ, Lima JA, Kronmal RA: Alcohol and coronary artery calcium prevalence, incidence, and progression: results from the Multi-Ethnic Study of Atherosclerosis (MESA). Am J Clin Nutr 2008;88:1593-1601.

46 Tofferi JK, Taylor AJ, Feuerstein IM, O’Malley PG: Alcohol intake is not associated with subclinical coronary atherosclerosis. Am Heart J 2004;148:803-809.

47 Ahmed HM, Blaha MJ, Nasir K, Jones SR, Rivera JJ, Agatston A, et al: Low-risk lifestyle, coronary calcium, cardiovascular events, and mortality: results from MESA. Am J Epidemiol 2013;178:12-21.

48 Ornish D, Scherwitz LW, Billings JH, Brown SE, Gould KL, Merritt TA, et al: Intensive lifestyle changes for reversal of coronary heart disease. JAMA 1998;280:2001-2007.

49 Haskell WL, Alderman EL, Fair JM, Maron DJ, Mackey SF, Superko HR, et al: Effects of intensive multiple risk factor reduction on coronary atherosclerosis and clinical cardiac events in men and women with coronary artery disease: the Stanford Coronary Risk Intervention Project (SCRIP). Circulation 1994;89:975-990.

50 Niebaurer J, Hambrecht R, Velich T, Hauer K, Marburger C, Kälberer B, et al: Attenuated progression of coronary artery disease after 6 years of multifactorial risk intervention: role of physical exercise. Circulation 1997; 96:2534-2541. 